Москвитин А. Ю.

\title{
Памяти друга
}

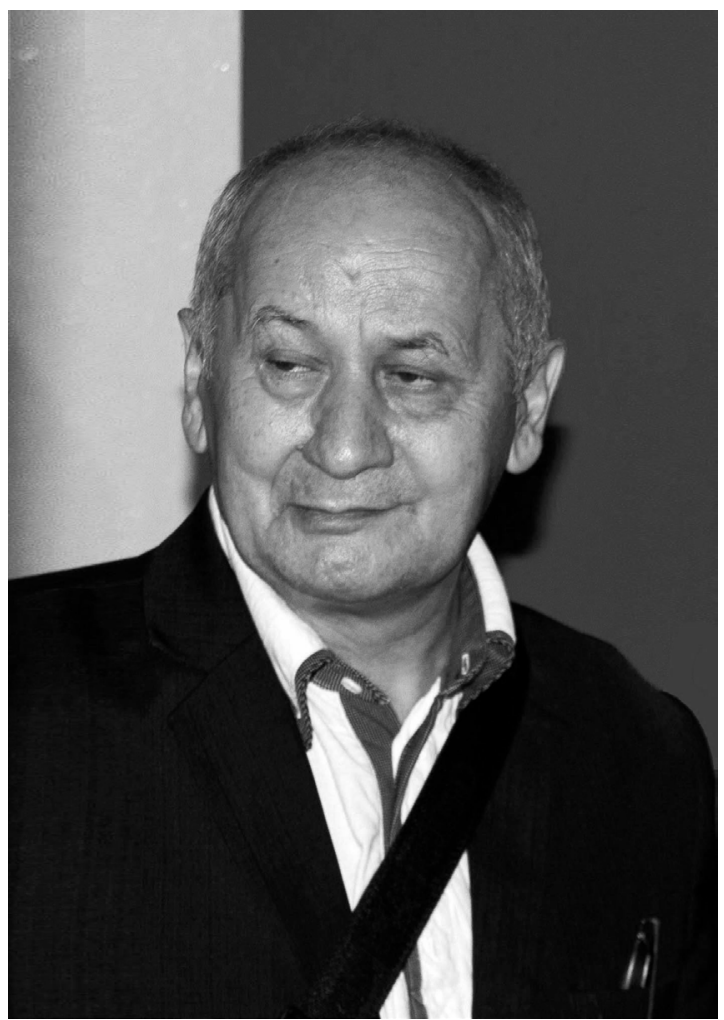

Михаил Григорьевич Ганопольский

3 ноября 2020 года ушел из жизни Михаил Григорьевич Ганопольский - доктор фрилософрских наук, профрессор кафедры транспорта углеводородных ресурсов Тюменского индустриального университета, главный научный сотрудник Института проблем освоения Севера Тюменского научного центра Сибирского отделения РАН, член редакционной коллегии журнала «Ойкумена. Регионоведческие исследования».

Михаил Григорьевич родился 6 декабря 1945 года в г. Кировограде и поэтому с улыбкой квалифицировал себя как «дитя победы». В 1970 году он окончил Одесский государственный университет по специальности «Математика» (именно эта математичность его ума, т.е. сочетание свободного воображения и строгих выводов, была тем, что удивило и привлекло меня, когда мы встретились). В 1971 году М.Г. Ганопольский переехал в Тюмень, где начал работать по специальности в Гипротюменьнефтегазе и СибНИПИгазстрое. Однако, начавшееся с развитием промышленной недтегазодобычи комплексное освоение региона, его демографические, социальные и духовные характеристики заинтересовали Михаила Григорьевича и изменили профессиональные приоритеты на исследовательские и педагогические. Он начал работу в Тюменском индустриальном университете, которому отдал 25 лет, - заведующим лабораторией, затем ведущим научным сотрудником НИИ прикладной этики, профрессором кафедры организации производства и внешнеэкономической деятельности Института менеджмента и бизнеса, профрессором кафедры транспорта углеводородных ресурсов Института транспорта ТИУ. С 1989 года он также работал в Институте проблем освоения Севера Сибирского отделения РАН. В 1981 году М.Г. Ганопольский защитил кандидатскую диссертацию «Управление нравственным воспитанием в трудовом коллективе: прикладные исследования и разработки», в 1998 году - докторскую диссертацию по фрилософии «Региональный этос: истоки, становление, развитие».

С Михаилом Григорьевичем я познакомился в 1988 году в (тогда еще) Свердловске, в Институте повышения квалификаџии (ИПК) Уральского госу-

МОСКВИТИН Андрей Юрьевич, канд. филос. наук, преподаватель Российского колледжа традиционной культуры (2. Санкт-Петербург). E-mail: aum07@mail.ru 
ниверситета, где я готовился к поступлению в аспирантуру, а он подступал к теме, ставшей предметом его докторской диссертации и последующих исследований - к проблеме регионального этоса. Не помню, что в тот день в книжном магазине выбрал я сам, но выбор старшего товарища запомнил хорошо: только что вышедший перевод Евы Анчел «Этос и история» и... 3-й том четырехтомника Аристотеля. На мое удивление: зачем ему древний Аристотель, да еще самые «нефилософрские» его сочинения? он удивил меня еще больше, признавшись, что Аристотель - один из его любимых писателей (sic!). Много лет позднее Михаил Григорьевич прокомментировал этот эпизод нашего общения как шутку, но для меня это оказалось серьезным уроком неутилитарного и неидеологического отношения к филлософиии.

В эти полгода (январь-июнь 1988) он еще много раз выводил меня из состояния наивно-догматического всёпонимания. Это могло быть его предложение

Министерство общего и профессионального образования Российской федерации

Тюменский государственный нефтегазовый университет Научно-исследовательский институт прикладной этики

Doporany tice gpeco topeloera c ronnumu zybi, boun kopres u sxaguna evere recueveeret

М.Г. Ганопольский

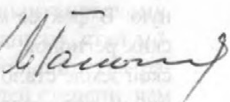

РЕГИОНАЛЬНЫЙ ЭТОС:

ИСТОКИ, СТАНОВЛЕНИЕ, РАЗВИТИЕ

Ответственный редактор доктор философских наук

В.И.Бакштановский

Тюмень $1998-2006$ описать красоту и особость

Владивостока, которое открывало мне, что город, который я уже десяток лет как считал своим, все еще не пережит и не прочувствован мною. И по возвращении я вновь открывал Владивосток, вглядываясь в него как бы глазами Михаила Григорьевича. Это могло быть его объяснение, - столь же меткое, сколь и объективное, - несомненного, но до времени необъяснимого для меня фракта особой привлекательности приморских девушек тем, что в их жилах текла кровь многих народов, осваивавших дальневосточный край. Это было его мужество, - спокойное, но непреклонное, - перед антисемитизмом, который к моему изумлению обнаружили некоторые коллеги-преподаватели, и которому он с улыбкой противостоял: «ибо не ведают, что творят».

В этих и других эпизодах М.Г. Ганопольский постепенно проявлялся для меня как человек рубежа, с интересом всматривавшийся в неизвестное, и вместе с тем сознающий себя носителем традиции, которая не только трансформируется в столкновении с новым, но и сама формирует это новое как порядок и обустроенность. Это симптоматично резонировало и его научным интересам, и собственной исследовательской траектории. Подсмеиваясь над тогдашними моими «истматовскими» приоритетами - теорией общественного прогресса и его критериев, Михаил Григорьевич советовал мне заняться этикой и уже серьезно предлагал реальную помощь - знакомство со своим старшим товарищем - доктором фрилософрских наук, В.Г. Ивановым - одним из создателей ленинградской школы этики...

Мы встретились еще раз через пару лет в Ленинграде: несколько часов общения, обмен новостями и планами и... возвращение в собственную уже отмеченную тревогой жизнь - Советский Союз доживал свои последние месяцы. Последующее общение протекало в письмах - сначала бумажных, затем 
электронных, потом пришло время SMS-сообщений и звонков. Неизменно любопытный к жизни Михаил Григорьевич интересовался тем, чем живет Владивосток, сетовал на то, что наступивший в России капитализм с его ресурсодобывающей доминантой отринул проблематику не узко экономического, но комплексного хозяйственного освоения Дальнего Востока и Западной Сибири, что проблематика регионального этоса, которым он продолжал занимался, стала интересна за рубежом - в Китае, Монголии, Казахстане, но не в России.

Поэтому столь актуальным и интересным оказалось для него прозвучавшее более десяти лет тому назад предложение молодых организаторов журнала «Ойкумена. Регионоведческие исследования» войти в состав редакционной коллегии. Новые темы, имена, профессиональные контакты, открывавшиеся ему на этой работе, помогали сохранять вкус к регионоведческим разработкам, позволяли не только удостоверять достигнутый научный уровень, но и продолжать актуальную исследовательскую работу. Работу, безвременно прервавшуюся за месяц до 75-летнего юбилея М.Г. Ганопольского.

В один из сложных моментов моей жизни, когда мне пришлось сделать непростой выбор, Михаил Григорьевич, не разделяя его, все же напутствовал меня: «В добрый час!». Думаю, многие из знавших этого человека, также могут вспомнить его честность и доброту. Светлая память, дорогой товарищ и друг!

\section{Москвитин А. Ю. Памяти друга.}

Moskvitin A. Yu. In memory of a friend.

Для цитирования: Москвитин А. Ю. Памяти друга // Ойкумена. Регионоведческие исследования. 2020. № 4. C. 164-166. DOI: 10.24866/1998-6785/2020-4/164-166

For citation: Moskvitin A. Yu. In memory of a friend // Ojkumena. Regional researches. 2020. № 1. P. 164-166. DOI: 10.24866/1998-6785/2020-4/164-166 